\title{
ELECTRIC MOTORS MAINTENANCE PLANNING FROM ITS OPERATING VARIABLES
}

\author{
Francisco RODRIGUES, Inácio FONSECA, José Torres FARINHA \\ Instituto Superior de Engenharia de Coimbra \\ Luís FERREIRA \\ Faculdade de Engenharia da Universidade do Porto \\ Diego GALAR \\ Luleå University of Technology
}

\begin{abstract}
:
The maintenance planning corresponds to an approach that seeks to maximize the availability of equipment and, consequently, increase the levels of competitiveness of companies by increasing production times. This paper presents a maintenance planning based on operating variables (number of hours worked, duty cycles, number of revolutions) to maximizing the availability of operation of electrical motors. The reading of the operating variables and its sampling is done based on predetermined sampling cycles and subsequently is made the data analysis through time series algorithms aiming to launch work orders before reaching the variables limit values. This approach is supported by tools and technologies such as logical applications that enable a graphical user interface for access to relevant information about their Physical Asset HMI (Human Machine Interface), including the control and supervision by acquisition through SCADA (Supervisory Control And data acquisition) data, also including the communication protocols among different logical applications.
\end{abstract}

Key words: maintenance, planned maintenance, electric machines, HMI/SCADA

\section{INTRODUCTION}

Nowadays, maintenance is one of the key factors for business productivity.

In most industrial processes the electric motor is an indispensable asset due to the fact that it is a core element (Fig. 1). However, there is a permanent increase in power consumption and, at the same time the need to reduce the consumption of fossil fuels. Since the electric motors are fundamental components for industrial systems, accounting for over $60 \%$ of its total electrical energy consumption, they must be balanced between a target maximum availability and the optimization of its electrical energy consumption.

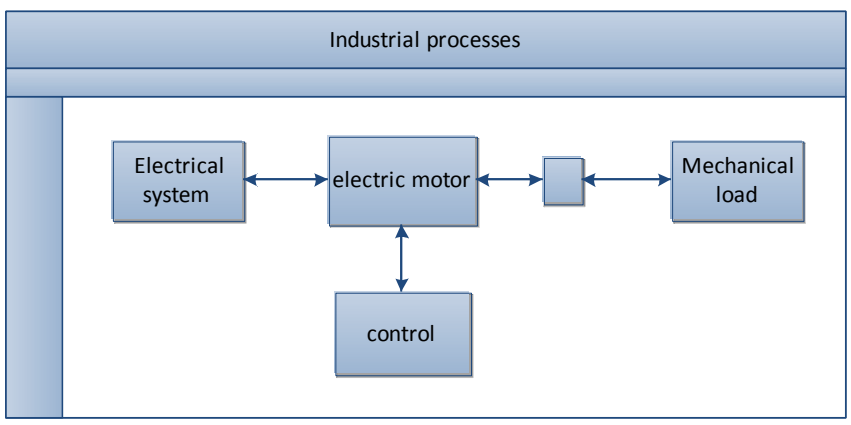

Fig. 1 General construction of industrial processes
The breakdown of an electric motor is quite simple and there is a limited number of components where just few of them can be considered critical for failure. Indeed, the operational life cycle of these devices depends on almost exclusively on the winding insulation systems. However, it can be affected by many factors such as moisture, vibration, corrosive environments, and poor design.

The preventive maintenance based on the threshold value determined by a control variable, usually allows to extend the operating life of electric motors [1].

It is this subject that is discussed throughout the article, whose structure is as follows:

Chapter I - Introduction,

Chapter II - State of the art,

Chapter III - Data acquisition,

Chapter IV - Operation variables and condition,

Chapter V - Maintenance Management,

Chapter VI - Used hardware and software,

Chapter VII - Monitoring and condition monitoring,

Chapter VIII - Application GESP,

Chapter IX - Conclusions,

Chapter X - Future developments.

\section{STATE OF THE ART}

The maintenance planning based on the control and monitoring of operating variables is not a cross-cutting approach to Computer Maintenance Management System 
(CMMS) on the market. Two of the most paradigmatic programs are as follows:

- Maximo [2] - is a CMMS developed by IBM [3], which allows to manage maintenance through its main aspects, having an IBM Maximo Calibration module where is possible to monitor the equipment,

- SAP R/3 [4] - is a CMMS developed by SAP AG, being a very horizontal system, i.e., is an integrated, modular software, but not specialized in CMMS shed. Due to SCADA Software Zenon interface with SAP R/3 it is possible to monitor the equipment and provide data to the application.

Given some limitations found therein a program it was developed an academic software tool, designated Gesp. This makes maintenance planning based on the monitoring and control of the operating condition variables and with the aid of the HMI/SCADA Zenon tool.

\section{DATA AQUISITION}

With the development and advent of SCADA, monitoring of physical variables can be performed by means of sensors and measurement devices using PLC [5] (Programmable Logic Control), which send the monitored data through protocols communication (ModBus [6] OMRON FINS [7], among others) which use several devices and software applications. The connections go through Fieldbus systems, and complex redundant network structures that can be compatible with all standards, such as OPC UA [8] (OLE for Process Control Unified Architecture), several IEC protocols [9] or Modbus, and with proprietary systems and several types of hardware.

Through the information provided by SCADA [10] systems, it can monitor default values and other control tasks. The SCADA system allows to perform monitoring, control, and draw up reports in real-time and historical data. Such systems correspond to HMI (Human Machine Interface) applications [11], which tend to grow due to the incessant demand, allowing secure, more flexible processes, and reducing users working time. The values of the operating variables and condition are the data provided by SCADA applications to different systems / maintenance applications [12] dealing with specific algorithms (Fig. 2).

\section{VARIABLE WORKING AND CONDITION}

The main variables to consider in an electric motor are: the chain; the tension; torque; and temperature. If the measured parameter values do not fall within the ranges that have been dimensioned, then current operation may affect the life of electric motors and deterioration of the materials and components that constitute them. Through monitoring tools they are triggered the alarm conditions giving rise to interventions (Fig. 3) - the sampling of the variables can be performed through either aperiodic or periodic cycles.

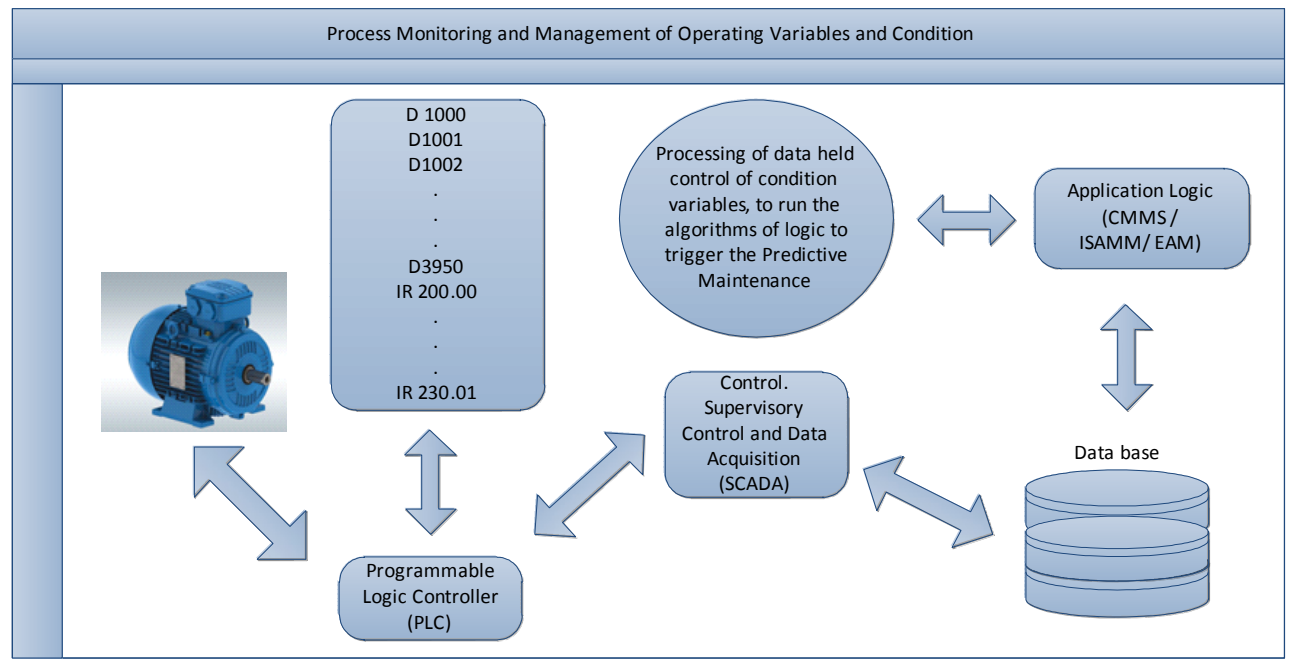

Fig. 2 Process for monitoring the operating and condition variables

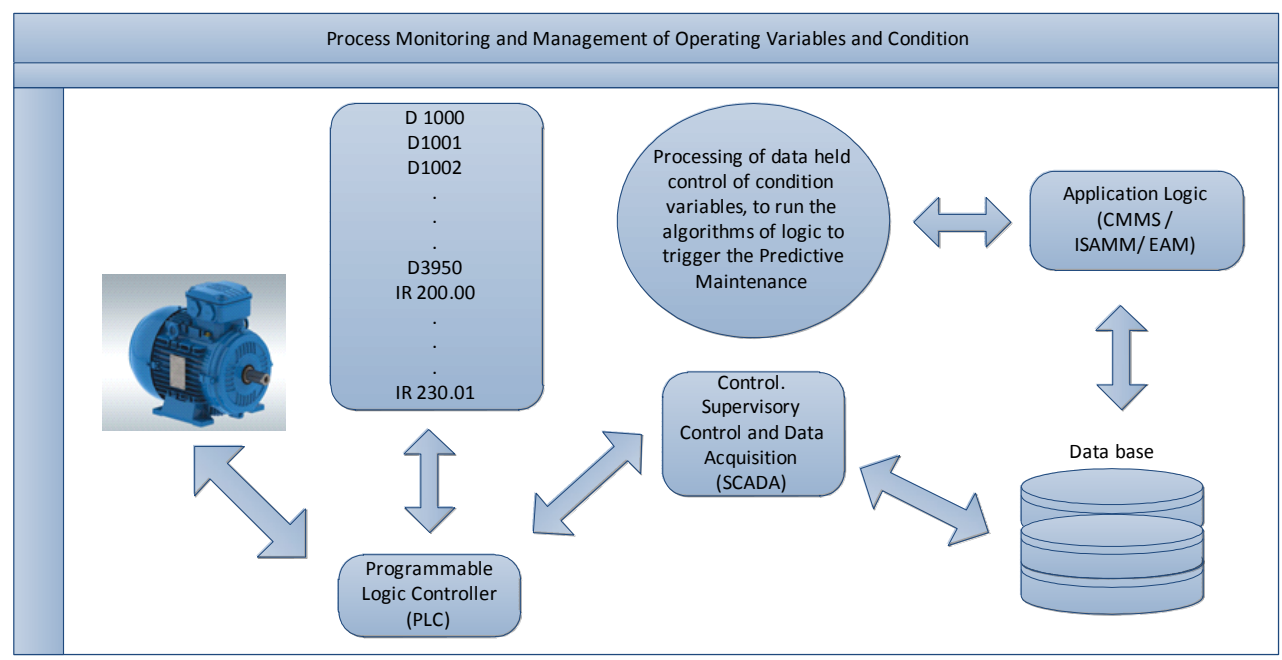


The use of these tools allows to monitor the operation of electric motors through its most significant variables for their performance to be the most appropriate.

\section{MAINTENANCE MANGEMENT}

The treatment of the variables mentioned in the previous chapter can be provided to a CMMS, either directly or through auxiliary modules. Thus, the maintainers can adjust not only their parameterization, but also their maintenance contracts as well as improvement actions [13] (Fig. 4).

Predictive maintenance [14] is performed according to the state of "health" of the equipment, including damage, if this is the previously planned condition. In general, associated to operating variables and condition, measures a given unit which, when they reach a certain threshold, giving rise to an intervention, as illustrated in Figure 3.

\section{HARDWARE AND SOFTWARE USED}

The hardware and software used are illustrated in Figure 5. In hardware stands out a variable speed drive, a power meter, an engine, an automaton and a module expansion analog inputs and outputs.

The FINS Protocol (TCP/IP) was used to obtain the data monitored by the PLC (via Ethernet), which, in turn, communicates with the energy meter through ModBus/RTU (RS -485 physical environment). The ModBus protocol uses the client-server type communication model (master/slave) the server should not initiate any communication on the media until it has been requested by the customer. To perform the communication via ModBuS protocol with the MX2 inverter, it must be set the parameters shown in Table 1.

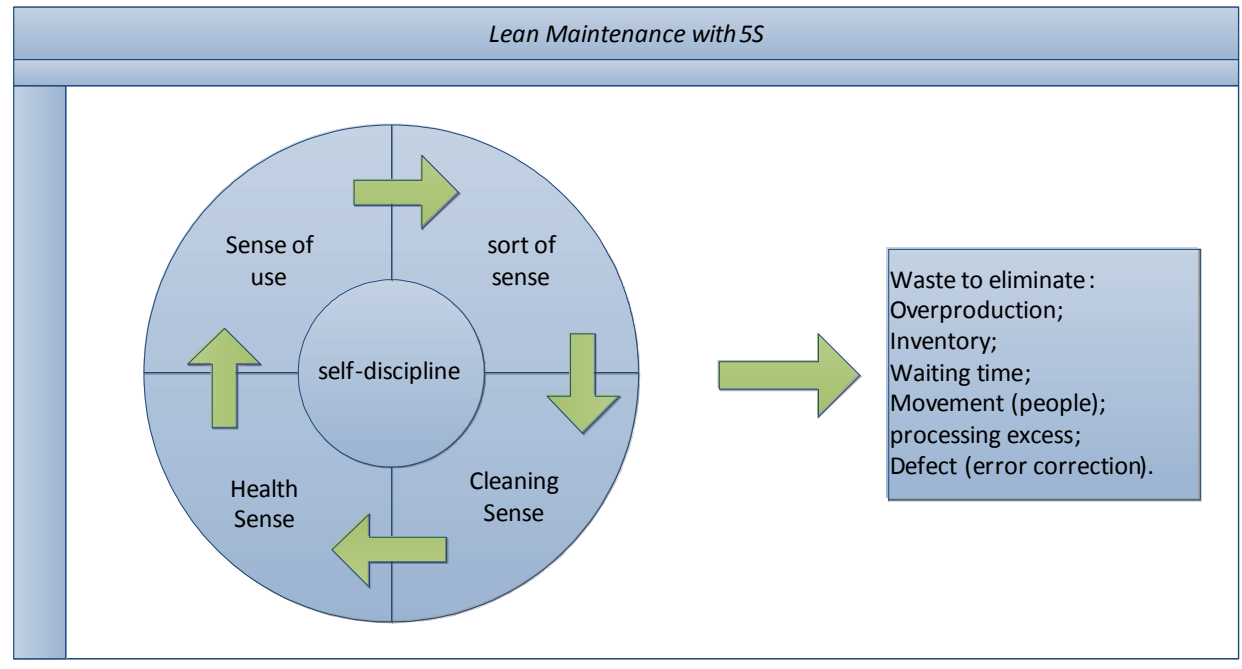

Fig. 4 New aspects for asset management

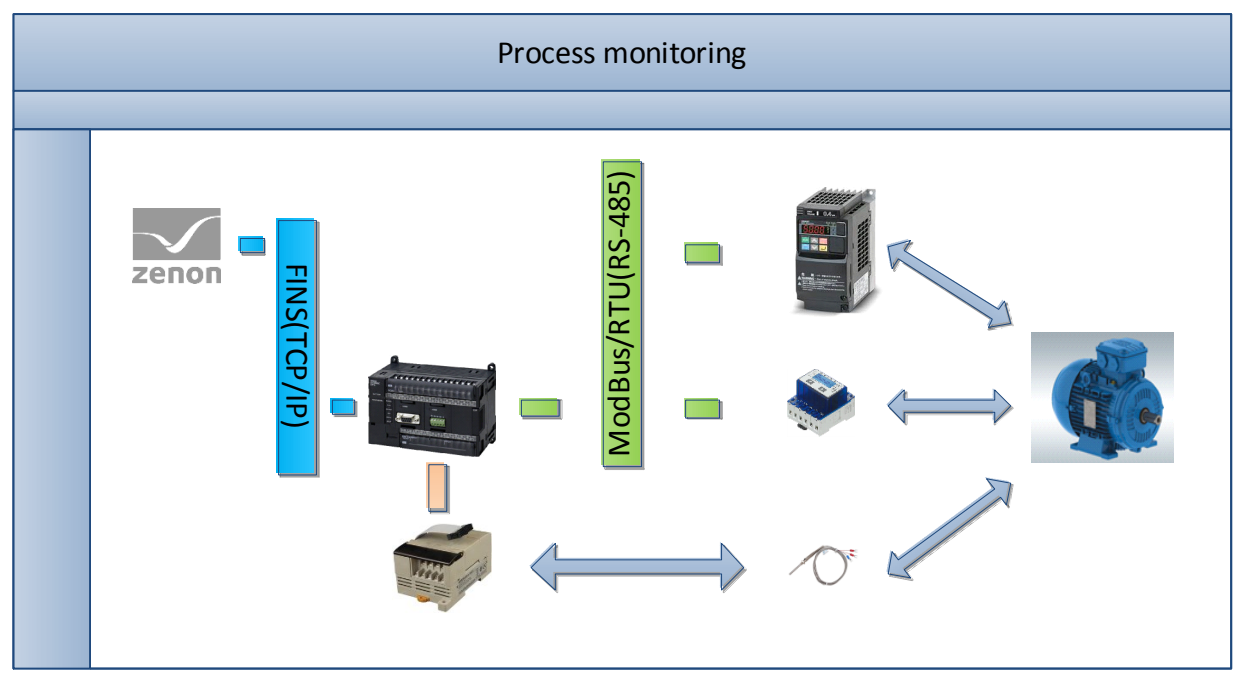

Fig. 5 Electric motor monitoring modules 


\begin{tabular}{|c|c|c|c|c|}
\hline \multicolumn{2}{|c|}{$\begin{array}{l}\text { Parâmetro } \\
\text { N. }{ }^{\circ}\end{array}$} & \multirow{2}{*}{$\begin{array}{l}\text { Nome da função } \\
\\
\text { Seleção da Velocidade } \\
\text { de Comunicação }\end{array}$} & \multirow[b]{2}{*}{$\begin{array}{l}\text { Variação do monitor ou de dados } \\
\text { 03: } 2.400 \text { bps } \\
04: 4.800 \text { bps } \\
05: 9.600 \text { bps } \\
\text { 06: } 19,2 \mathrm{kbps} \\
07: 38,4 \mathrm{kbps} \\
08: 57.6 \mathrm{kbps} \\
09: 76,8 \mathrm{kbps} \\
\text { 10: } 115,2 \mathrm{kbps}\end{array}$} & \multirow{2}{*}{$\begin{array}{c}\text { Unidade } \\
\text { - }\end{array}$} \\
\hline 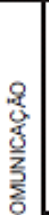 & $\operatorname{co71}$ & & & \\
\hline 品 & $\operatorname{Co72}$ & $\begin{array}{l}\text { Seleção do } \mathrm{N}^{0} \text {. da } \\
\text { Estação de Comunicação }\end{array}$ & 1, a 247 & - \\
\hline \begin{tabular}{l|l}
8 \\
3 \\
3 \\
3 \\
4
\end{tabular} & $\mathrm{CO} 074$ & Seleção da Paridade & $\begin{array}{l}\text { 00: Sem paridade } \\
\text { 01: Par } \\
\text { 02: Impar }\end{array}$ & - \\
\hline & $\mathrm{C} 075$ & Seleção do Bit de Parada & $\begin{array}{l}1: 1 \text { bit } \\
\text { 2: } 2 \text { bits } \\
\end{array}$ & - \\
\hline \multicolumn{2}{|c|}{$\begin{array}{l}\text { Parâmetro } \\
\text { N.० }\end{array}$} & Nome da função & Variação do monitor ou de dados & Unidade \\
\hline \multirow{3}{*}{ 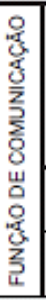 } & $\operatorname{co76}$ & $\begin{array}{l}\text { Seleção de Operação } \\
\text { sob Erro de } \\
\text { Comunicação }\end{array}$ & $\begin{array}{l}\text { 00: Trip (Desligamento) } \\
\text { 01: Trip (Desligamento) após parada de } \\
\text { desaceleração } \\
\text { 02: Ignorado } \\
\text { 03: Parada em inércia } \\
\text { 04: Parada por controle em desaceleraçäo }\end{array}$ & \\
\hline & $\mathrm{C} 077$ & $\begin{array}{l}\text { Limite de Tempo de Erro } \\
\text { de Comunicação }\end{array}$ & $\begin{array}{l}\text { 0,00: Limite de tempo desabilitado } \\
0,01 \text { a } 99,99\end{array}$ & s \\
\hline & $\operatorname{co78}$ & $\begin{array}{l}\text { Tempo de Espera de } \\
\text { Comunicação }\end{array}$ & 0. a 1000 & $\mathrm{~ms}$ \\
\hline \multicolumn{2}{|c|}{$\begin{array}{l}\text { Parâmetro } \\
\text { N. }{ }^{\circ}\end{array}$} & Nome da função & Variação do monitor ou de dados & Unidade \\
\hline \multirow{4}{*}{ 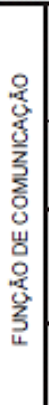 } & $\operatorname{Cog6}$ & Seleção de Comunicação & $\begin{array}{l}\text { 00: Comunicaçǟo Modbus (Modbus-RTU) } \\
\text { 01: Comunicaçäo como coinversor } \\
\text { 02: Comunicação como co-inversor } \\
\text { (inversor gerenciador da rede) }\end{array}$ & - \\
\hline & $\mathrm{C} 098$ & $\begin{array}{l}\text { Número da Estação de } \\
\text { Início de Comunicação } \\
\text { como Co-Inversor }\end{array}$ & 1, a 8 & - \\
\hline & $\operatorname{cog}$ & $\begin{array}{l}\text { Número da Estação de } \\
\text { Conclusão de } \\
\text { Comunicação com o } \\
\text { Co-Inversor }\end{array}$ & 1, a 8 , & \\
\hline & $\mathrm{C} 100$ & $\begin{array}{l}\text { Seleção de início de } \\
\text { comunicaçäo como } \\
\text { co-inversor }\end{array}$ & $\begin{array}{l}\text { 00: Via } 485 \\
\text { 01: Sempre iniciado }\end{array}$ & - \\
\hline
\end{tabular}

\section{Fig. 6 ModBus protocol parameters used in the MX2 inverter}

For the selection of the material used for monitoring the engine parameters it is necessary to know which are the values of its operating system given by the manufacturer. This data is contained in signage plate of the electric motor, as shown in Figure 7.

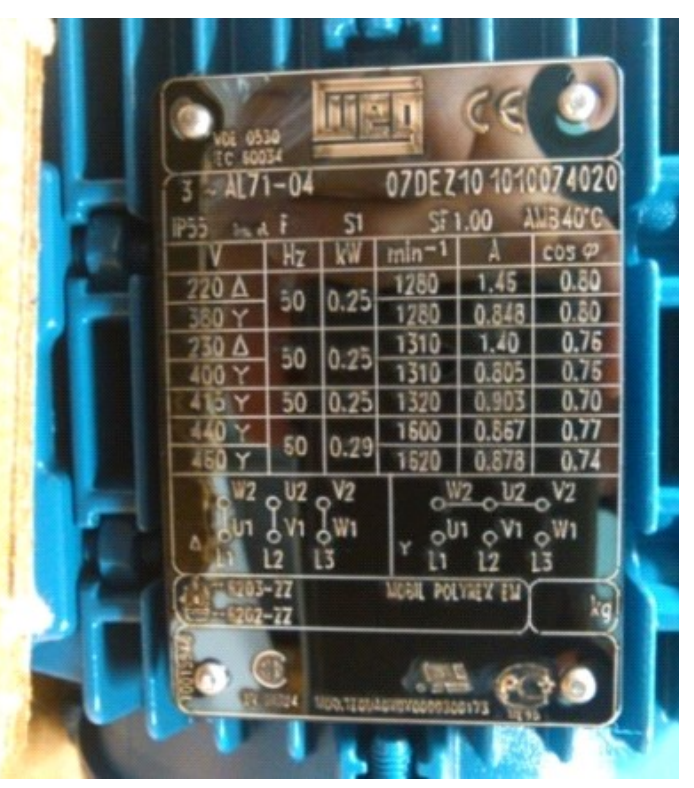

Fig. 7 Nameplate of the electric motor
To perform the logic control and monitoring of the operating variables and conditions, it is used the PLC [15] shown in Figure 8, that performs the logic control through its bit input and output and or analog S MAD01 connecting the analog input/output of the inverter as shown in Figure 9. Another possible configuration is through an inverter control by the RS-485 network, as well as the energy meter, as illustrated in Figure 10 - running both through ModBus protocol - which provides control and data storage of operating variables and conditions in the PLC memory area.

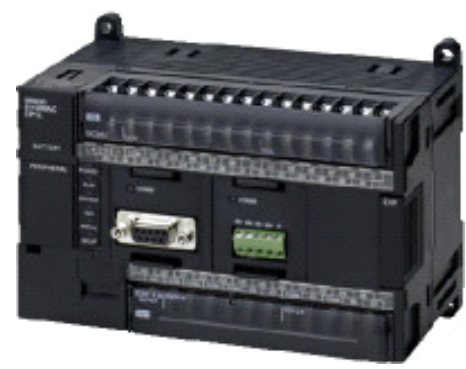

\section{Fig. 8 Nameplate of the electric motor}

To perform engine control frequency for the analog inputs of the inverter and to monitor the temperature, it is necessary to use a module, illustrated in Figure 9, for converting the analog values for input/output of data to the PLC [16]. 


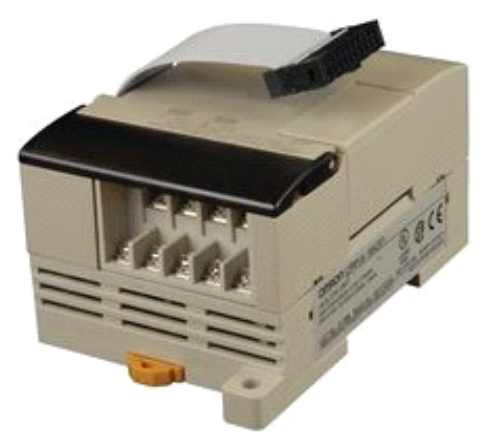

Fig. 9 OMRON Module analog inputs and outputs CPM1AMAD01

If the current is high it will be necessary to use IT (current transformers), such as illustrated in Figure 13, with characteristics adapted to the energy meter used - in this case it was used the counter illustrated in Figure 12.

For the control of electric induction motor it is used a static frequency converter [17] (Figure 10) that is a solution that has been adopted increasingly in industry. The drive in question allows for control and monitoring the engine parameters. The inverter can be controlled by analog inputs, by control panel, and also through the Modbus communication protocol. The modes of control are configurable ei- ther on local keyboard or by specific OMRON software. The inverter is parameterized as described in Fig. 13.

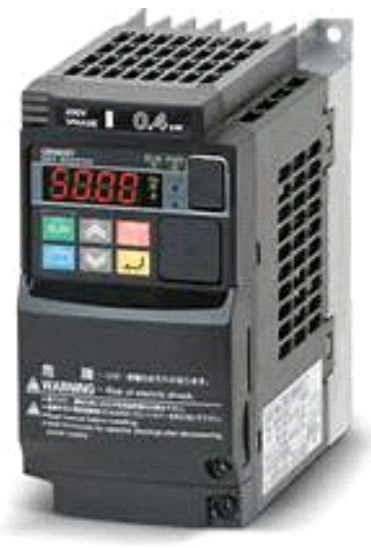

Fig. $10 \mathrm{MX2}$ Inverter Omron

According to Figure 13, between the drive and the engine it is included an energy meter [18] which allows the energy monitoring that is supplied to the motor (current, voltage, active power, reactive power, and the cos factor power).

\begin{tabular}{|c|c|c|c|}
\hline $\begin{array}{l}\text { Paràmetro } \\
\mathbf{N}^{\circ}\end{array}$ & Nome da funçäo & Variação do monitor ou de dados & Unidade \\
\hline d001 & $\begin{array}{l}\text { Monitor de } \\
\text { Frequência de } \\
\text { Saída }\end{array}$ & $\begin{array}{l}0.00 \text { a } 99,89 \\
100,0 \text { a } 1.000 \text {. (Modo de alta } \\
\text { frequéncia) }\end{array}$ & $\mathrm{Hz}$ \\
\hline d002 & $\begin{array}{l}\text { Monitor da } \\
\text { Corrente de } \\
\text { Saida }\end{array}$ & 0,0 a 655,3 & A \\
\hline d003 & $\begin{array}{l}\text { Monitor do } \\
\text { Sentido de } \\
\text { Rotacăo }\end{array}$ & $\begin{array}{l}\text { F: Avançar } \\
\text { o: Parar } \\
\text { r. Recuar }\end{array}$ & - \\
\hline d004 & $\begin{array}{l}\text { Monitor do Valor } \\
\text { de Feedback } \\
\text { para PID }\end{array}$ & $\begin{array}{l}0,00 \text { a } 99,99 \\
100,0 \text { a } 999,9 \\
1000, \text { a } 9999, \\
1000, \text { a } 9999,(10000, \text { a } 99990,) \\
0100 \text { a } 0999(100000, \text { a } 999000,)\end{array}$ & - \\
\hline d005 & $\begin{array}{l}\text { Monitor de } \\
\text { Entrada } \\
\text { Multifunçăa }\end{array}$ & 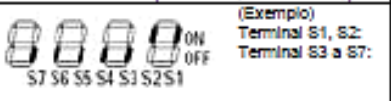 & - \\
\hline d006 & $\begin{array}{l}\text { Monitor de } \\
\text { Saída } \\
\text { Multifuncão }\end{array}$ & 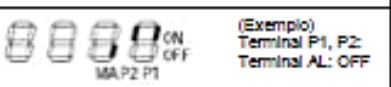 & - \\
\hline d007 & $\begin{array}{l}\text { Monitor da } \\
\text { Frequência de } \\
\text { Saida (após } \\
\text { conversăo) }\end{array}$ & $\begin{array}{l}0,00 \text { a } 99,99 \\
100,0 \text { a } 999,9 \\
1000, \text { a } 4000,(9999,) \\
1000, \text { a } 4000,(9999 / 0100)\end{array}$ & - \\
\hline d008 & $\begin{array}{l}\text { Monitor da } \\
\text { Frequência Real }\end{array}$ & $\begin{array}{l}(-100 /-999,)-400, a-100, \\
-99,9 \text { a }-10,0 \\
-9,89 \text { a }-0,00 \\
0,00 \text { a } 99,99 \\
100,0 \text { a } 400,0(400,1 \text { a } \\
999,8 / 1000,)\end{array}$ & $\mathrm{Hz}$ \\
\hline d009 & $\begin{array}{l}\text { Monitor de } \\
\text { Referência de } \\
\text { Torque }\end{array}$ & $-200, a \div 200$ & $\%$ \\
\hline d010 & $\begin{array}{l}\text { Monitor de } \\
\text { Tendência (Bias) } \\
\text { de torque }\end{array}$ & $-200, a \div 200$ & $\%$ \\
\hline d012 & $\begin{array}{l}\text { Monitor de } \\
\text { Torque de Saida }\end{array}$ & $-200, a+200$ & $\%$ \\
\hline d013 & $\begin{array}{l}\text { Monitor de } \\
\text { Tensắo de } \\
\text { Saída }\end{array}$ & 0,0 a 600,0 & $\mathrm{v}$ \\
\hline d014 & $\begin{array}{l}\text { Monitor da } \\
\text { Potência de } \\
\text { Entrada }\end{array}$ & 0,0 a 100,0 & kW \\
\hline
\end{tabular}

\begin{tabular}{|c|c|c|c|}
\hline $\begin{array}{l}\text { Parämetro } \\
\text { N.: }\end{array}$ & Nome da funçąo & Varlaçào do monitor ou de dados & Unidade \\
\hline d015 & $\begin{array}{l}\text { Monltor de } \\
\text { Consumo }\end{array}$ & $\begin{array}{l}0,0 \text { a 999,9, } \\
1000, \text { a } 9999, \\
1000, \text { a } 9999,(10000, \text { a } 99990,) \\
{[100, \text { a }[999,(100000, \text { a } 999000,)}\end{array}$ & - \\
\hline d016 & $\begin{array}{l}\text { Tempo de } \\
\text { Trabalho }\end{array}$ & $\begin{array}{l}0,0 \text { a } 9999, \text {, (10000, a } 99990,) \\
1000, \text { a } 9999, \text {, } \\
{[100, \text { a } 1999,(100000, \text { a } 999000,)}\end{array}$ & $n$ \\
\hline d017 & $\begin{array}{l}\text { Tempo } \\
\text { Energlzado }\end{array}$ & $\begin{array}{l}0,0 \text { a } 9999, \\
1000,39999,\{10000, \text { a 99990, }\} \\
{[100, \text { a } 1999,(100000, \text { a } 999000,\}}\end{array}$ & $n$ \\
\hline d018 & $\begin{array}{l}\text { Monltor de } \\
\text { Temperatura do } \\
\text { Dissioador }\end{array}$ & $-20,0$ a 150,0 & ${ }^{\circ} \mathrm{C}$ \\
\hline $\mathrm{d} 022$ & $\begin{array}{l}\text { Monltor de } \\
\text { Avaliaçăto da } \\
\text { Vlda do Produto }\end{array}$ & 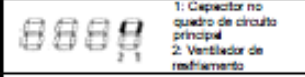 & - \\
\hline$\frac{d 023 a}{d 027}$ & (Reservado) & - & - \\
\hline$d 029$ & $\begin{array}{l}\text { Monltor de } \\
\text { Comando de } \\
\text { Poslça }\end{array}$ & $\begin{array}{l}-268435455 \text { a } 258435455 \\
\text { (Exibe } 4 \text { digtos de MSB Incluindo } \\
\therefore)\end{array}$ & - \\
\hline d030 & $\begin{array}{l}\text { Monltor de } \\
\text { Posiģ5o Real }\end{array}$ & $\begin{array}{l}-268435455 \text { a } 268435455 \\
(\text { Exibe } 4 \text { digtos de MSB Inciulndo } \\
\Rightarrow)\end{array}$ & - \\
\hline d050 & $\begin{array}{l}\text { Monlitor de } \\
\text { Seleçäo de } \\
\text { Usuario (2 thpos) }\end{array}$ & $\begin{array}{l}\text { Exibe os dados do monltor } \\
\text { selecionados por b16ab } 161 .\end{array}$ & - \\
\hline d050 & $\begin{array}{l}\text { Monltor de } \\
\text { Modo do } \\
\text { Inversor }\end{array}$ & 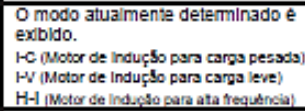 & - \\
\hline d080 & $\begin{array}{l}\text { Contador de } \\
\text { Falhas }\end{array}$ & $\begin{array}{l}0, \text { a } 9999, \\
1000, \text { a } 6553,(10000, a 65530,)\end{array}$ & Tempo \\
\hline d081 & $\begin{array}{l}\text { Monlitor de } \\
\text { Falhs } 1 \\
\text { (Recente) }\end{array}$ & \multirow{6}{*}{$\begin{array}{l}\text { Causa } \\
\text { - Frequencla (Hz) } \\
\text { - Corrente (A) } \\
\text { - Tensaso entre PNs (V) } \\
\text { - Tempo de TRAEALHO (h) } \\
\text { - Tempo ENERGIZADO (h) }\end{array}$} & \multirow{6}{*}{ - } \\
\hline $\mathrm{d} 032$ & $\begin{array}{l}\text { Monltitor de } \\
\text { Falh3s } 2\end{array}$ & & \\
\hline d083 & $\begin{array}{l}\text { Monltior de } \\
\text { Falhas } 3 \\
\end{array}$ & & \\
\hline d034 & $\begin{array}{l}\text { Monltitor de } \\
\text { Falhas } 4\end{array}$ & & \\
\hline dos5 & $\begin{array}{l}\text { Monltor de } \\
\text { Falh3s } 5\end{array}$ & & \\
\hline d036 & $\begin{array}{l}\text { Monlitor de } \\
\text { Falhas } 6\end{array}$ & & \\
\hline$\triangle 090$ & $\begin{array}{l}\text { Monltor de } \\
\text { Alerta }\end{array}$ & Codigo de Alerta & - \\
\hline $\mathrm{d} 102$ & $\begin{array}{l}\text { Monltior de } \\
\text { Tensto de DC }\end{array}$ & $\begin{array}{l}0,0 \text { a } 999,9 \\
1000 .\end{array}$ & $\mathrm{v}$ \\
\hline d103 & $\begin{array}{l}\text { Monitor de Nivel } \\
\text { de Frenagem } \\
\text { Regenerattva (\%) }\end{array}$ & 0,0 a 100,0 & $\%$ \\
\hline d104 & $\begin{array}{l}\text { Monltor de Rele } \\
\text { de Proteçäo } \\
\text { Temlca - } \\
\text { Sobrecarga (\%) }\end{array}$ & 0,0 a 100,0 & $\%$ \\
\hline
\end{tabular}


The temperature measurement can also be performed through the ADC, or the energy meter, given that it has a system of inputs for the acquisition of analog signals [19].

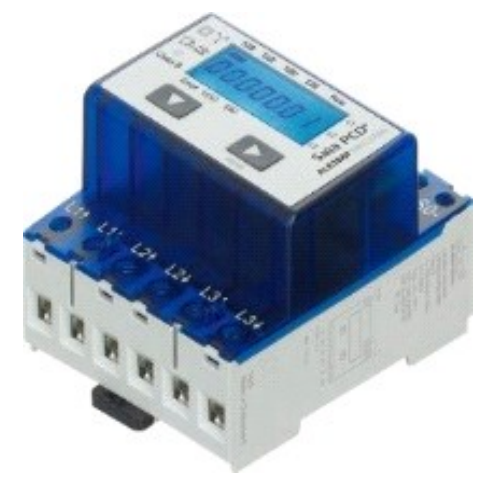

Fig. 12 Three-phase energy meter SBC SAIA-ALE3D5F11 Class B

A possible solution for the monitoring of motors phase currents is through the use of IT [20] if the current range is beyond the limits of the energy meter (Figure 13) or, if the model energy meter requires IT external (the ALE3 [21] does not require IT to current until 65 Ampere).

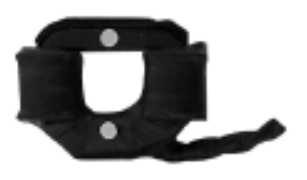

Fig. 13 CTY intensity transformers
For the selection of IT, it is necessary to know the range of current values which the engine operates taking into account the values of the upper and lower current limits. In this case, the motor runs at a nominal current of $1.40 \mathrm{~A}$. From the table of the FLEX-CORE manufacturer [22] and data of IT mentioned above, reported in Table 3 (CTY model) the selected IT for that current range is CTY-A. The IT is selected by the thicknesses of the wires through which the current, the current range in which they will work, and the necessary capacity with which the IT needs to monitor the streams.

The engine manufacturer [23] used in this project has four solutions, as shown in Table 2, comprising devices that have its own thermal protection. For the triggering of maintenance through the temperature control, only the first three solutions can be used because they are the ones that allow their monitoring.

Resistance Term (Pt-100) - are temperature sensors with a high degree of accuracy and sensitivity response, but correspond to a very viable solution economically due to the sensors and the electronics associated to the control is costly.

The thermistors (PTC and NTC) - temperature control in the implementation of thermistor has a low cost when compared to the Pt-100. Although it is necessary to use a relay for the control and actuation.

Thermal protectors Bimetallic/Thermostats - the use of thermostats for the maintenance trigger has to be appropriate for action by raising the expected engine temperature.

Protective Thermal Phenolic - they have the particularity of being sensitive to current and temperature, enabling automatic control. It is limited to the current in the case the protector is connected directly to the coil of the singlephase motor and can only be used in three-phase motors connected in $\mathrm{Y}$.

Table 1

Intensity transformers range from CITY model FLEX-CORE

\begin{tabular}{|c|c|c|c|c|c|c|c|}
\hline \multirow[t]{2}{*}{ INPUT AC AMPS } & \multicolumn{6}{|c|}{ STANDARD OUTPUTS MODEL CTY- } & \multirow[t]{2}{*}{ SENSOR SIZE } \\
\hline & 0-0.1Aac* & 0-1Aac & $0-5$ Aac & $0-0.333$ Vac & $0-1$ Vac & $0-5 \mathrm{Vac}$ & \\
\hline $0-50$ & 050A-.1 & 050A-1 & NA & 050A-.3V & 050A-1V & 050A-5V & A \\
\hline $0-100$ & $100 \mathrm{~A}-.1$ & $100 \mathrm{~A}-1$ & NA & $100 \mathrm{~A}-.3 \mathrm{~V}$ & $100 \mathrm{~A}-1 \mathrm{~V}$ & $100 \mathrm{~A}-5 \mathrm{~V}$ & A \\
\hline $0-200$ & $200 A-.1$ & $200 A-1$ & NA & $200 \mathrm{~A}-.3 \mathrm{~V}$ & $200 A-1 V$ & $200 A-5 V$ & A \\
\hline $0-100$ & 100B-.1 & 100B-1 & 100B-5 & 100B-.3V & 100B-1V & 100B-5V & B \\
\hline $0-200$ & 200B-.1 & 200B-1 & 200B-5 & 200B-.3V & 200B-1V & 200B-5V & B \\
\hline $0-300$ & 300B-.1 & 300B-1 & $300 B-5$ & 300B-.3V & $300 B-1 V$ & $300 B-5 V$ & B \\
\hline $0-400$ & 400B-.1 & 400B-1 & 400B-5 & 400B-.3V & 400B-1V & 400B-5V & B \\
\hline $0-500$ & 500B-.1 & 500B-1 & 500B-5 & 500B-.3V & 500B-1V & 500B-5V & B \\
\hline $0-600$ & 600B-.1 & 600B-1 & $600 B-5$ & 600B-.3V & $600 \mathrm{~B}-1 \mathrm{~V}$ & $600 B-5 V$ & B \\
\hline $0-800$ & 800B-.1 & $800 B-1$ & $800 B-5$ & 800B-.3V & $800 \mathrm{~B}-1 \mathrm{~V}$ & 800B-5V & B \\
\hline $0-800$ & $800 C-.1$ & $800 C-1$ & $800 C-5$ & $800 \mathrm{C}-.3 \mathrm{~V}$ & $800 \mathrm{C}-1 \mathrm{~V}$ & $800 \mathrm{C}-5 \mathrm{~V}$ & $\mathrm{C}^{* *}$ \\
\hline $0-1000$ & 1000C-.1 & $1000 \mathrm{C}-1$ & $1000 C-5$ & $1000 \mathrm{C}-.3 \mathrm{~V}$ & 1000C-1V & $1000 \mathrm{C}-5 \mathrm{~V}$ & $\mathrm{C}^{* *}$ \\
\hline $0-1200$ & 1200C-.1 & 1200C-1 & $1200 C-5$ & 1200C-.3V & 1200C-1V & $1200 C-5 V$ & $\mathrm{C}^{* *}$ \\
\hline
\end{tabular}


Thermal protection devices presented by WEG

\begin{tabular}{|c|c|c|c|c|}
\hline & Term resistance & $\begin{array}{l}\text { Thermistor } \\
\text { (PTC e NTC) }\end{array}$ & Thermal protector bimetal & $\begin{array}{c}\text { Phenolic Thermal } \\
\text { Protector }\end{array}$ \\
\hline $\begin{array}{l}\text { Protection } \\
\text { mechanism }\end{array}$ & Resistance calibrated & Avalanche resistance & Movable contacts Bimetallic & Movable contacts \\
\hline Disposition & Head wound & Head wound & $\begin{array}{l}\text { Inserted in the circuit } \\
\text { Bobbin Head }\end{array}$ & Inserted in the circuit \\
\hline Acting form & $\begin{array}{c}\text { External operations } \\
\text { command in protection }\end{array}$ & $\begin{array}{c}\text { External operations } \\
\text { command in protection }\end{array}$ & $\begin{array}{c}\text { Direct action } \\
\text { External control } \\
\text { protection to work }\end{array}$ & Atuação direta \\
\hline Current limit & Chain of command & $\begin{array}{l}\text { Chain } \\
\text { of command }\end{array}$ & $\begin{array}{l}\text { Motor current chain of com- } \\
\text { mand }\end{array}$ & Motor current \\
\hline Sensitivity Type & Temperature & Temperature & Current and Temperature & $\begin{array}{l}\text { Current and } \\
\text { Temperature }\end{array}$ \\
\hline $\begin{array}{l}\text { Number of motor } \\
\text { units }\end{array}$ & 3 or 6 & 3 or 6 & $\begin{array}{l}3 \text { or } 6 \\
1 \text { or } 3\end{array}$ & 1 \\
\hline Command types & Alarm and/or cut & Alarm and/or cut & $\begin{array}{c}\text { Court } \\
\text { Alarm and/or cut }\end{array}$ & Court \\
\hline $\begin{array}{l}\text { Technological } \\
\text { feasibility }\end{array}$ & Very good & Satisfactory & Good & Unsatisfactory \\
\hline Affordability & Unsatisfactory & Very good & Satisfactory & Satisfatória \\
\hline $\begin{array}{l}\text { Technological and } \\
\text { financial viability }\end{array}$ & Satisfatória & Satisfactory & Good & Unsatisfactory \\
\hline
\end{tabular}

\section{CONDITION MONITORING AND CONTROL}

In most industrial processes that use electric motors, the sensors described above, not only for their protection but also for their monitoring, have been integrated. In this case, a simulation was made with the engine running without load. The main objective was to monitor and control engine operation, as illustrated in Figure 14, including the simulation of a fault.

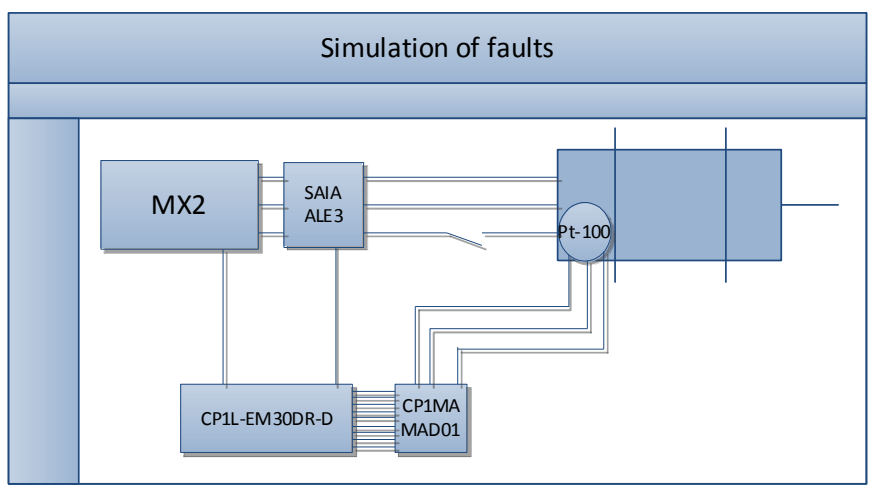

Fig. 14 Fault simulation monitoring

To perform the test trigger a condition of intervention, it is necessary to monitor the feeding phases of the induction motor. Cutting the power stage (with a switch) of the engine it was carried out. In this case, the current will tend towards a minimum predetermined value in the algorithm implemented in the control system. The engine malfunction gives rise to this work with only two phases, thus unbalancing the operating system, which means that its temperature rise [24], and may exceed the upper limit of good operating system and activate other maintenance trigger. The cause of the simulated fault can damage the engine due to the material properties do not have ability to with- stand such high temperatures. In the event of a threshold value which lead to the triggering of an intervention, a Work Order is issued with a set of procedures, such as checking the status of the electrical connections of the engine, among others.

\section{GESP APPLICATION}

To support the study presented in the previous chapters it has been developed an information system [25] that allows initiating the maintenance interventions according to the value of equipment monitoring data. The data communicationfrom the application is carried out through the use of SCADA Software Zenon [26], which allows data acquisition through a PLC that monitors information from an inverter through whitch engine is running. The data monitored by Zenon can be saved by communicating with the SQL Server database [27] through SQL system driver. Data acquisition by PLC is made by OMRON FINS driver (TCP/IP). Both variables, to be created, are allocated in the same function, as can be seen in Figure 15.

System monitoring is carried out according to the scheme illustrated in Figure 16. It uses two different system technologies, both of which have to be synchronized to perform both operations.

Operating variables and condition are monitored by the Scheduling Meter.

As shown in Figure 17, triggering a maintenance intervention is made using two types of monitoring: (1) Meter Scheduling; (2) Control and Scheduling.

As shown in Figure 18, 19 it is used the Zenon SCADA software to send the data of the variables monitored by Gesp database application to perform the interventions. This software SCADA, in addition to the monitoring variables from the electric motor interface, and its associated logic CP1L-EM30DR-D programming (programming software, Ladder) can monitor and control the electric motor. 


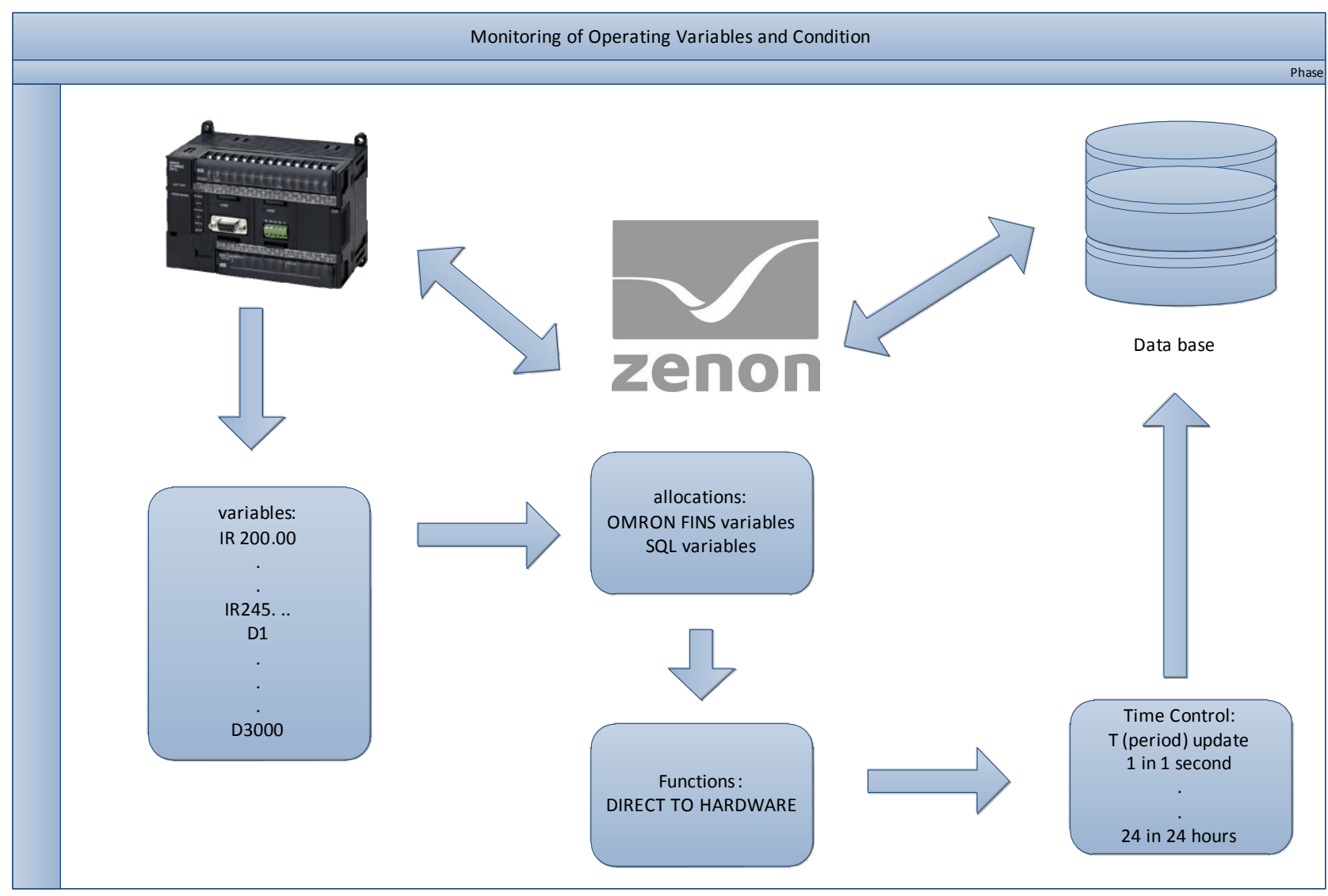

Fig. 15 Monitoring and allocation of the operating and condition variables

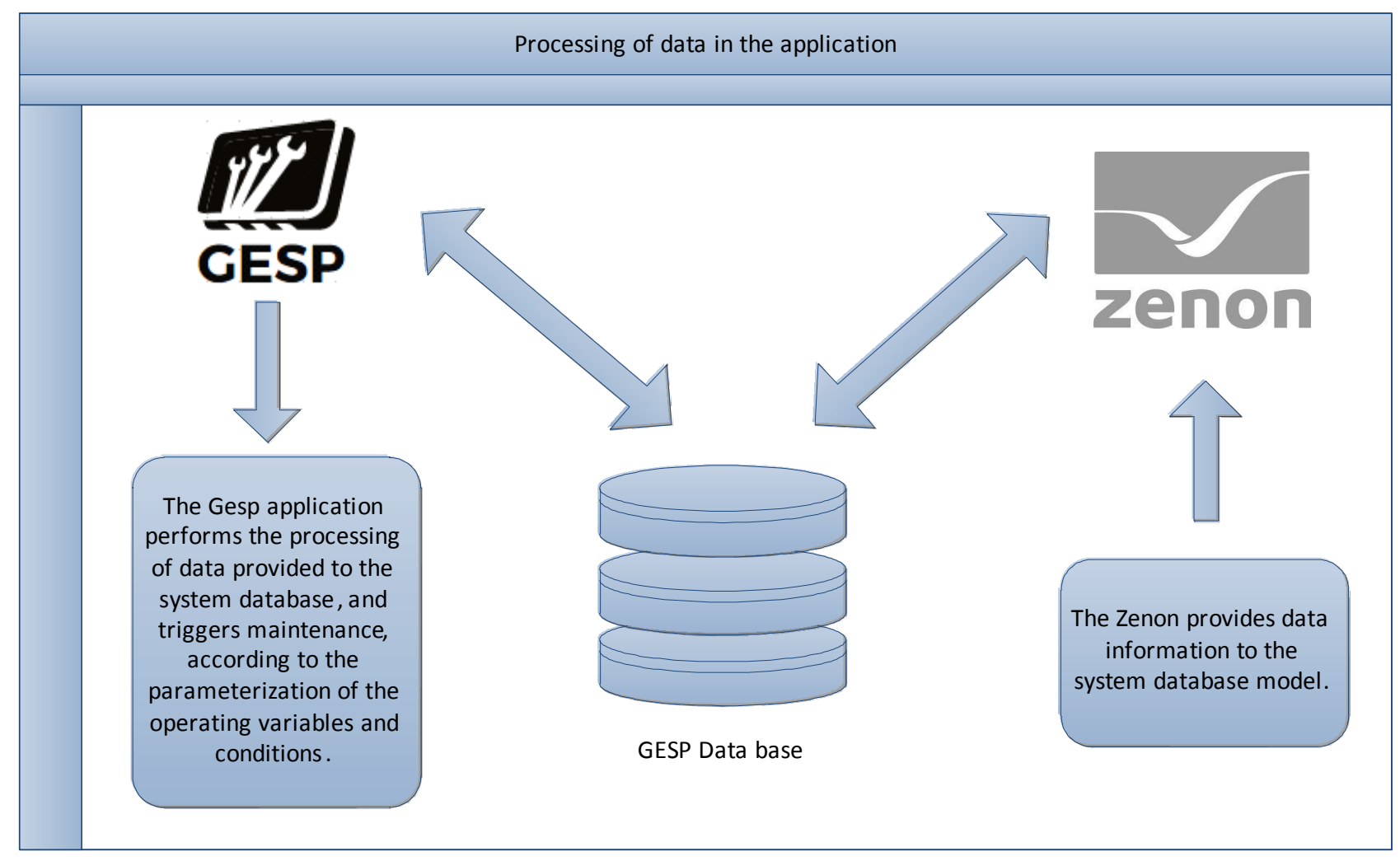

Fig. 16 Monitoring and control of planned maintenance 


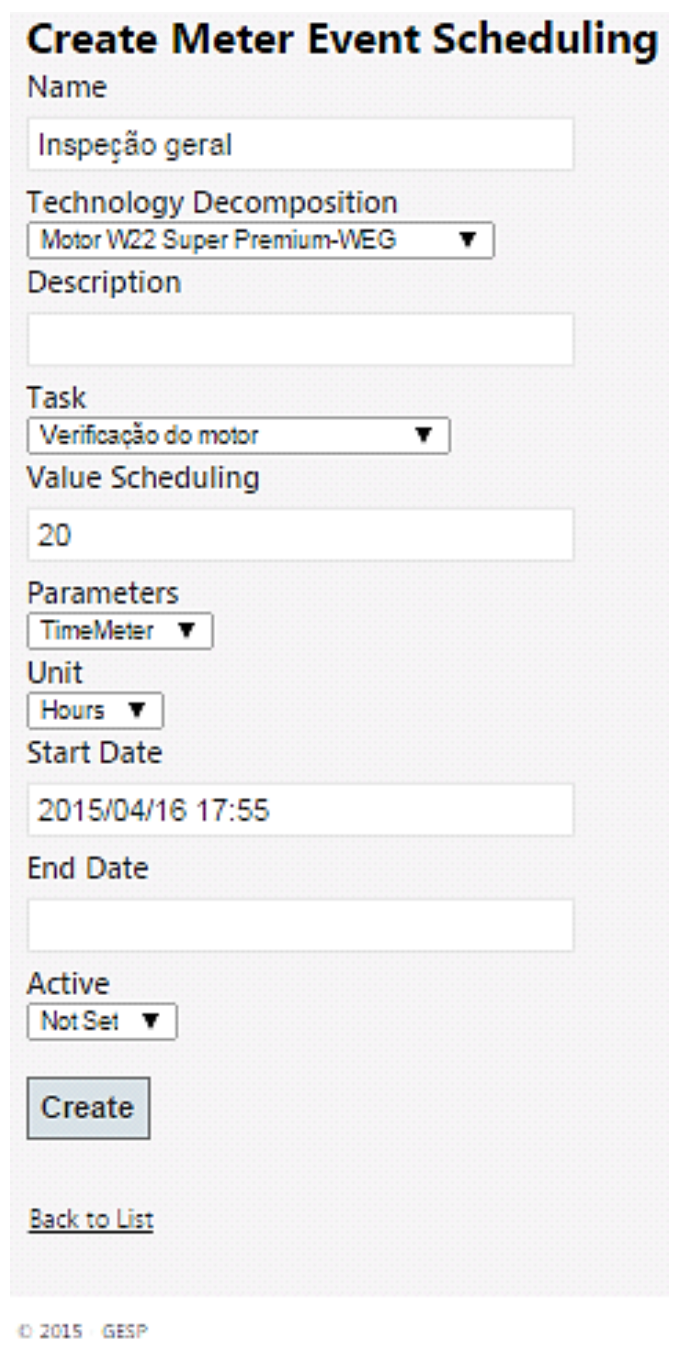

Fig. 17 Creation of view of conditional maintenance trigger

CURRENT

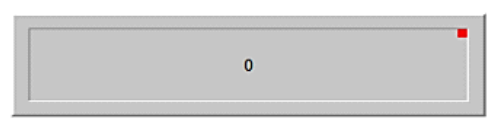

TORK
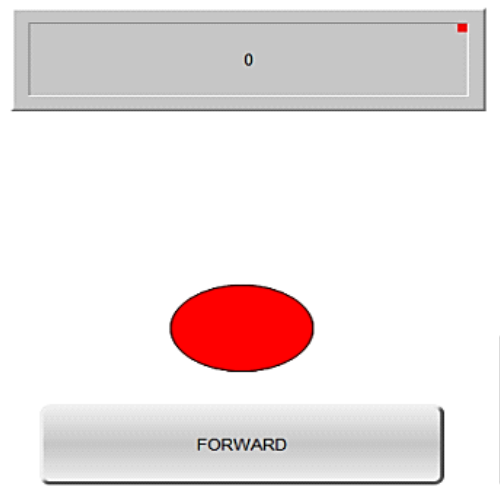

VOLTAGE

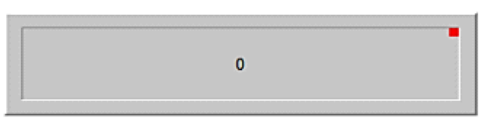

TEMPERATURE
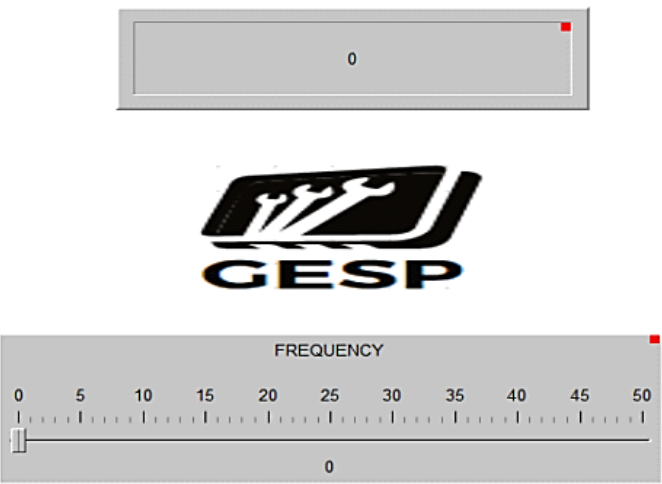

TOTAL TIME

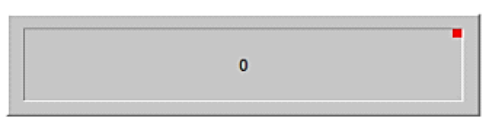

METER TIME

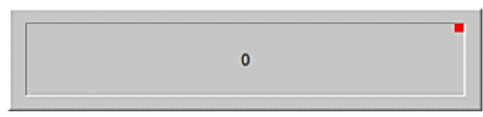

RESET
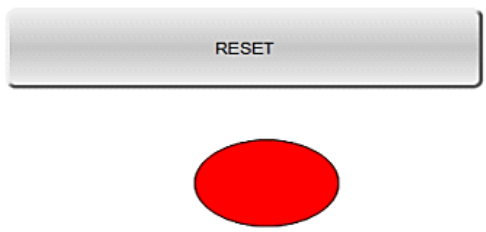

REVERSED 
Welcom to GESP Information System Applied to Maintenance Management

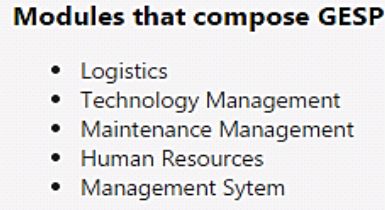

Fig. 19 View from the main menu of the software application yasmim GESP

According to illustrated in Figure 20 it is possible that the user knows if there was a request.

\section{Scheduling Meter}

\section{You have new events to manage: „ Verificação das tolerâncias de aperto}

Fig. 20 Illustration of the trigger intervention

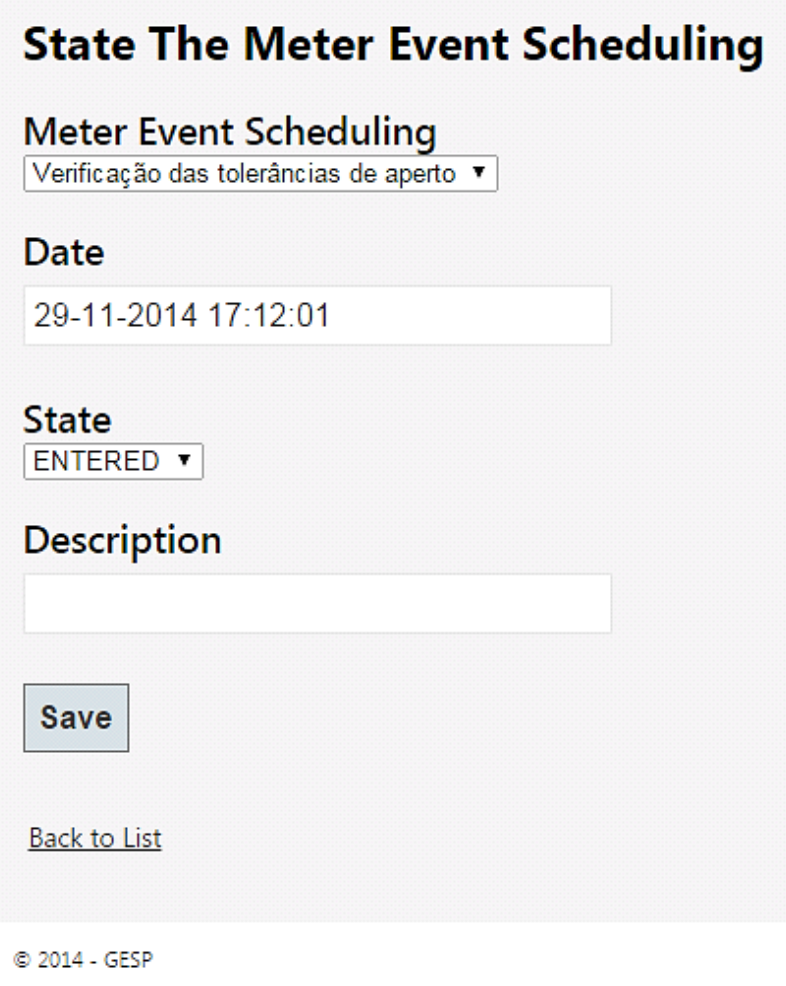

Fig. 21 Illustration of state of an intervention trigger

\author{
Scheduling Meter \\ No events \\ Scheduling Control \\ No events
}

Scheduling Regular

No events

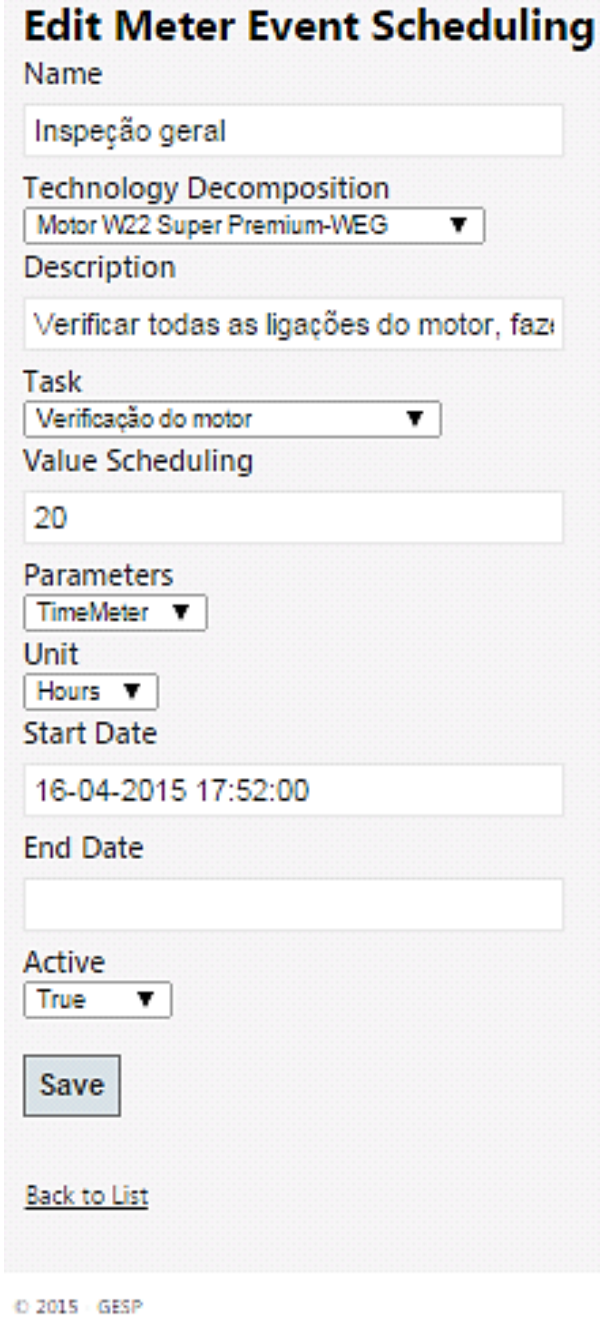

Fig. 22 Edit view of the trigger intervention

Figure 23 shows the process of monitoring and control of operating variables and condition for triggering an intervention in GESP application. 


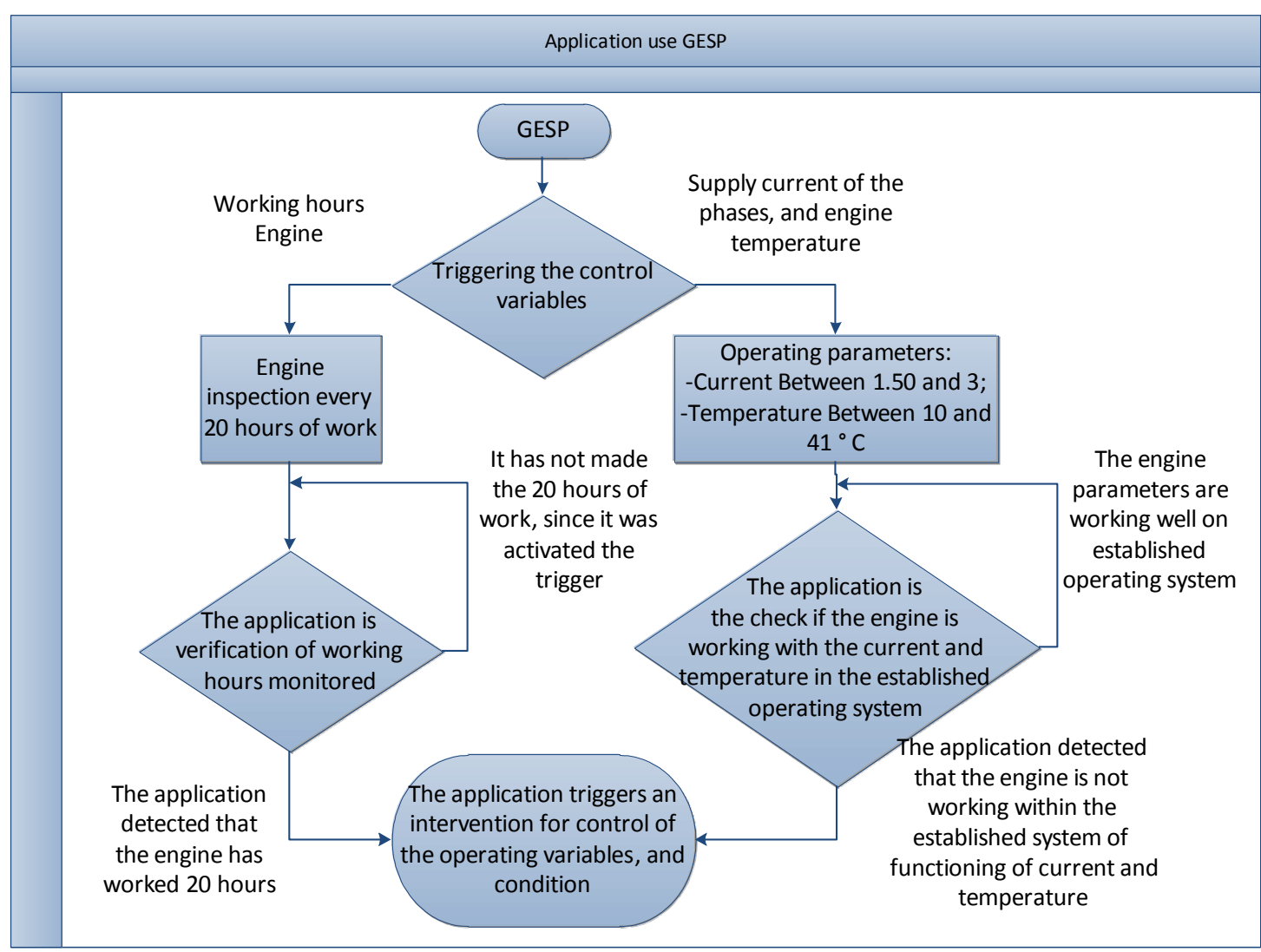

Fig. 23 GESP Application

\section{FURURE DEVELOPTMENS}

The next challenge to be reached by the system is the development of a scheduling system in real-time, prospecting an automatic maintenance management, embedded with a failure prediction model based on dynamic modeling, where a historical analysis of the physical assets, the monitoring and the analysis of critical features will be made.

The next version of the proposed system (GESP) aims to manage maintenance operations with greater autonomy and robustness, being the tasks selected automatically by the system and evaluated the alternatives with respect to human resources.

It is estimated that the maintenance condition assumes particular relevance in the following years as well as the application of e-Maintenance concept [13]. In maintenance condition sector several studies were performed, one of them highlights a prediction model applied to wind generators based on vibration analysis [14], or a failure prediction by the analysis of other variables based on the historical of physical assets [15].

Due to the high degree of complexity of performing maintenance interventions, paper-based instructions are falling into disuse, being replaced by its equivalent in electronic version to be accessed by tablets or smartphones. The use of these devices opens doors to new horizons as the introduction of augmented reality in industrial environments [16], a technology that consists of superimposing virtual content to the real environment, which allows to display, on intuitive way, the sequence of instructions that technician must perform.

\section{CONCLUSIONS}

Planning maintenance from its operating variables helps to maximize the availability of equipment and therefore to increase the levels of competitiveness of companies by increasing production times. For its implementation the papers shows that through the use of adequate technology and algorithmic tools applied to operating variables and the equipment condition through periodic and aperiodic sampling cycles can be reached better planning. The monitoring and control are made by integrating SCADA (Supervisory Control and Data Acquisition) using communication protocols between the several application logics which allow reliable transmission of data. The triggering of the maintenance work is done by processing the data of the control variables using specific algorithms to monitor and launch automaticaly the Work Orders before damage can occur with reference values previously specified limit.

\section{REFERENCES}

[1] J.M.T. Farinha, "Ferramentas de Apoio à Manutenção", in Manutenção. A Terologia e as Novas Ferramentas de Gestão. Lisbon: Monitor, 2011, pp. 56 $-58$.

[2] International Business Machines Corporation. (2012, September 22). IBM Software [Online]. Available: http://www-01.ibm.com/software/tivoli/

[3] Internacional Business Machines Corporation. (2012, August 5). IBM Home [Online]. Available: http:// www.ibm.com/us/en

[4] SAP AG. (2012, September 26). SAP R/3 [Online]. Available: http://help.sap.com/r3/ 
[5] Wikipedia. (2014, October 5). Programmable logic controller [Online]. Available: http://en.wikipedia.org/ wiki/Programmable_logic_controller

[6] ModBus Organization. (2014, September 5). ModBus [Online]. Available: http://www.modbus.org/

[7] Wikipedia. (2014, September 5). FINS [Online]. Available: http://en.wikipedia.org/wiki/FINS

[8] OPC Foundation. (2014, September 7). Home page [Online]. Available: https://opcfoundation.org/

[9] International Electrotechnical Commission. (2014, September 8). Home page [Online]. Available: http:// www.iec.ch/

[10] Wikipedia. (2014, September 8). SCADA [Online]. Available: http://en.wikipedia.org/wiki/SCADA

[11] Wikipedia. (2014, September 8). User interface [Online]. Available: http://en.wikipedia.org/wiki/ User_interface

[12] Wikipedia (2014, September 8). Computerized maintenance management system [Online]. Available: http:// en.wikipedia.org/wiki/ Computerized_maintenance_management_system

[13] J.M.T. Farinha, "Novas Vertentes da Gestão", in Manutenção. A Terologia e as Novas Ferramentas de Gestão. Lisbon: Monitor, 2011, pp. 79-82.

[14] J. M. T. Farinha, "O conceito de Manutenção e Sua Evolução", in Manutenção. A Terologia e as Novas Ferramentas de Gestão. Lisbon: Monitor, 2011, pp. 810.

[15] OMORON. (2014, September 4). Catalogue Programmable Logic Controller Compact PLC Series CP1L [Online]. Available: http://industrial.omron.eu/en/ products/catalogue/automation_systems/ programmable_logic_controllers/compact_plc_series/ cp1l/default.html

[16] Newark element 14. (2014, September 4). OMRON INDUSTRIAL AUTOMATION CPM1A-MAD01 ANALOG I/ $O$ MODULES [Online]. Available: http:// www.newark.com/omron-industrial-automation/ cpm1a-mad01/analog-i-o-modules/dp/19C7862

[17] OMRON (2014, October 20). Frequency Inverters Compact Solutions MX2 [Online]. Available: http:// industrial.omron.eu/en/products/catalogue/ motion_and_drives/frequency_inverters/ compact_solution/mx2/default.html

[18] SBC-SAIA BURGESS CONTROLS. (2014, November 6). Saia $P C D^{\circledR}$ Energy Meters [Online]. Available: https:// www.sbc-support.com/en/product-index/axx-energymeters/

[19] SBC-SAIA BURGESS CONTROLS. (2014, November 6). Energy management-Capture consumption [Online]. Available: $\quad$ http://www.saia-pcd.com/en/energymanagement/the-system/

[20] Flex-Core. (2014, November 6). CURRENT TRANSFORMERS/TRANSDUCERS [Online]. Available: http:// www.flex-core.com/current-transformerstransducers.htm

[21] SBC-SAIA. (2014, November 20). System Catalogue [Online]. Available: https://www.sbc-support.com/ flippingbooks/SystemCatalogue/26-215_en12/ index.html\#136/z

[22] Flex-Core, SPLIT CORE CURRENT TRANSFORMERS MODEL CTY, McVey Blvd. Columbus, Ohio: Flex-Core.

[23] Motores Elétricos - Guia de Especificações, Grupo WEG - Unidade Motores, Jaraguá do Sul, 2014, pp. 37 -38 .

[24] Wikipedia. (2014, November 5). Resistance thermometer [Online]. Available: http://en.wikipedia.org/wiki/ Resistance_thermometer

[25] F. Rodrigues, I. Fonseca, R. Oliveira and J.T.M. Farinha, "Maintenace Management in Web ASP.NET MVC Applications", in Proc. of Maintenance, Performance, Measurement and Management, Coimbra, Portugal, 2014, pp. 95-102.

[26] Copa Data. (2014, December 6). Software HMI SCADA zenon da COPA-DATA [Online]. Available: http:// www.copadata.com/

[27] Microsoft. (2012, June 5). SQL Server [Online]. Available: http://www.microsoft.com/en-us/server-cloud/ products/sql-server/

[28] CP1L CPU Unit - Operation Manual, OMRON, 2014.

[29] MX2 Manual, OMRON, 2014.

[30] Using Expansion Units and Expansion I/O Units, OMRON, 2014.

[31] OMRON. (2014, November 20). Omron website [Online]. Available: http://www.omron.com/

[32] WEG. (2014, November 4). WEG website [Online]. Available: http://www.weg.net/

[33] Flex-Core. (2014, November 5). Current Transducers [Online]. Available: http://www.flex-core.com/current -transducers.htm

\footnotetext{
Francisco Rodrigues, MSc, Eng. Assistat prof. Inácio Fonseca, prof. José Torres Farinha

Instituto Superior de Engenharia de Coimbra

Centre for Mechanical Engineering of the University of Coimbra

Rua Antero de Quental 195, 3000-033 Coimbra, PORTUGAL

e-mail: franciscocardos0@hotmail.com, inacio@isec.pt, tfarinha@isec.pt

\section{Luís Ferreira, Eng.}

Faculdade de Engenharia da Universidade do Porto

Praça de Gomes Teixeira, 4099-002 Porto, PORTUGAL

e-mail: Iferreir@fe.up.pt

prof. Diego Galar

Luleå University of Technology

97187 Luleå, SWEDEN

e-mail: diego.galar@ltu.se
} 